\title{
Cladia aggregata (lichen) from Brazilian Northeast: Chemical Characterization and Antimicrobial Activity
}

\author{
Mônica Cristina Barroso Martins ${ }^{1}$, Marcio James Gonçalves de Lima ${ }^{1}$, Flávia Pereira \\ Silva $^{1}$, Eulália Azevedo-Ximenes ${ }^{2}$, Nicácio Henrique da Silva ${ }^{1,3}$, Eugênia Cristina Pereira ${ }^{4 *}$ \\ ${ }^{1}$ Programa de Pós Graduação em Bioquímica e Fisiologia. ${ }^{2}$ Departamento de Antibióticos. ${ }^{3}$ Departamento de \\ Bioquímica; Centro de Ciências Biológicas; Universidade Federal de Pernambuco; Recife - PE - Brasil. \\ ${ }^{4}$ Departamento de Ciências Geográficas; Centro de Filosofia e Ciências Humanas; Universidade Federal de \\ Pernambuco; Av. Acadêmico Hélio Ramos, s/n; 50740-530; Recife - PE - Brasil.
}

\begin{abstract}
The chemical composition and antimicrobial activity of the Cladia aggregata (Sw.) Nyl. were evaluated. Barbatic acid, depside obtained from C. aggregata, was spectroscopically analyzed and tested, as well as organic extracts. The extracts and purified substance were tested against four Staphylococcus aureus multi-resistant strains. The structure of barbatic acid was confirmed through $N M R\left({ }^{1} H ;{ }^{13} \mathrm{C}\right)$ and elemental ${ }^{\circledR}$ analysis. Biochromatographic assays showed action of this compound, along with other substances contained in organic extracts, suggesting a synergic action, MIC assays placed barbatic acid in the same level of inhibition to other studied lichen substances.
\end{abstract}

Key words: Cladia aggregata, barbatic acid, antimicrobial activity

\section{INTRODUCTION}

In spite of being described as a symbiotic association between the photosynthetic organisms and fungi, lichens are highly complex communities that produce peculiar substances with phenolic characteristic, such as the barbatic, usnic and fumaprotocetraric acids (Honda and Vilegas, 1999). Those substances come from the secondary metabolism and are known as lichen acids. The production of these acids can vary from 0,1 to $10 \%$ of thallus dry weight, depending on the environmental conditions (Piovano et al., 2002). Lichen substances have been used for centuries (Llano, 1951). Their metabolites possess several biological properties such as antitumor (Santos et al., 2006), antiinflamatory (Vijayakumar et al.,
2000; Maia et al., 2002), antimicrobial (Piovano et al., 2002; Falcão et al., 2002; Ingólfsdóttir, 2002), antiparasitary (Carvalho et al., 2005), besides their action as UV sun blockers (Rancan et al., 2002) and efficiency as bioaccumulators and bioindicators of air quality, due to their ability of retaining contaminants, mainly heavy metals (Krishna et al., 2003; Monnet et al., 2005).

The presence of phenolic derivatives in lichen is determinant for its antimicrobial activity. These substances generally acidify the bacterial cell and, consequently, cause cytoplasm membrane rupture, inactivate the enzymes, and interfere on the electrons transport process and in the oxidative phosphorilation (Mueller, 2001; Randhir et al., 2004; Vattem et al., 2004).

*Author for correspondence: eugenia.pereira@pq.cnpq.br 
Some lichen species strongly depend on climatic and/or microclimatic conditions for producing different compounds, phenolics to pigments (Legaz et al., 1986). In C. aggregata, the typical characteristic of adaptation is its phenotypic plasticity (Filson, 1981). This species is capable of producing morphotypes that depends on the environmental conditions. This polymorphism results in some difficulties for specimens' identification. This is the reason of the existence of several descriptions made by different specialists that consider $C$. aggregata as $C$. coralloides and Cladonia genus, with many synonyms (Ahti, 1980). C. aggregata has the barbatic acid as the main compound, besides other substances such as the stictic, norstictic and fumarprotocetraric acids, whose occurrence depends on the area where the lichen is found. On the other hand, the specimens containing barbatic acid are considered as Brazilian chemotype (Ahti et al., 1993). Barbatic acid and usnic acid are reported as efficient against microorganisms, cancer cells and tumors (Pereira et al., 1994; Pereira et al., 1997).

In preliminary studies, organic extracts and barbatic acid from $C$. aggregata collected in Minas Gerais State, showed antimicrobial property against Bacillus cereus (UFPEDA - 39) (unpublished data). Thus, the aim of the present study was evaluate the chemical composition of $C$. aggregata and the antimicrobial activity of its purified barbatic acid against four multi-resistant Staphylococcus aureus strains. This is the first report of this species from Pernambuco State.

\section{MATHERIAL AND METHODS}

\section{Lichen material}

Cladia aggregata (Sw.) Nyl. was collected in Bonito, Pernambuco State, Northeastern of Brazil. The material was identified through morphological and chemical thallus characteristics. An exsiccate was kept on UFP Herbarium of Universidade Federal de Pernambuco - Brazil voucher $n^{\circ}$ 36431.

\section{Occurrence area description}

The Brazilian northeast possesses a humid and warm climate in its coast, and semi arid in the west side. Bonito County is located in the interface between humid and semi arid landscapes (about $132 \mathrm{~km}$ from the coast). In its territory there are several hills, with places at $800 \mathrm{~m}$ over sea level. This situation produces forest with high humidity and low temperatures, during the winter, lower than the ones registered in the coast. Due to mountains, rocks arise in areas like plateaus, where Cladoniaceae species occurs in large quantities.

Preparation of organic extracts and Natural thalli of $C$. agregata $(50 \mathrm{~g})$ were successively extracted with diethyl ether, chloroform and acetone in Soxhlet apparatus at $40^{\circ} \mathrm{C}$ for $8 \mathrm{~h}$. The extracts were concentrated, weighed and kept in dessecator (Pereira et al., 1996). Thalli of C. aggregata (50g) were extracted in Soxhlet apparatus at $40^{\circ} \mathrm{C}$ with diethyl ether for $8 \mathrm{~h}$. The ether extract was washed four times in G4 funnel with chloroform until crystal formation (Asahina, 1954).

\section{Chemical characterization of $C$. aggregata and identification of barbatic acid (BAR)}

Part of the ether extract of $C$. aggregata and the purified crystals of barbatic acid were analyzed by TLC (Culberson, 1972), in "A" solvent system (toluene/dioxan/acetic acid, 180:45:5, v/v), with posterior spray of $\mathrm{H}_{2} \mathrm{SO}_{4}(10 \%)$ and heating at $100^{\circ} \mathrm{C}$, until spots color reaction. HPLC assays carried out in a Hitachi Chromatograph, coupled to an UV detector $(254 \mathrm{~nm})$ at room temperature (28 $\pm 3^{\circ} \mathrm{C}$ ), under the following conditions: Merck $\mathrm{C}_{18}$ reverse phase column $(254 \times 4.6 \mathrm{~mm})$, isocratic solvent system, $\mathrm{MeOH}, \mathrm{H}_{2} \mathrm{O}$, acetic acid $(80: 19.5: 0.5, \mathrm{v} / \mathrm{v})$ at $1,0 \mathrm{~mL} \cdot \mathrm{min}^{-1}$, volume of injection $20 \mu \mathrm{L}$, attenuation 0.04 (Legaz and Vicente 1983). The samples were diluted at 1.0 $\mathrm{mg} / \mathrm{mL}$ (extracts), or $0.1 \mathrm{mg} / \mathrm{mL}$ (purified BAR and standards).

The elemental analysis of BAR was developed in a Carlo Erba analyzer model EA 1110, from 3mg of purified substance.

${ }^{1} \mathrm{H}$ and ${ }^{13} \mathrm{C}$ NMR spectra were recorded in a Varian Unity Plus 300 spectrometer. The ${ }^{13} \mathrm{C}$ NMR carried out at $75 \mathrm{MHz}$ and ${ }^{1} \mathrm{H}$ at $300 \mathrm{MHz}$, using DMSO-d6 as solvent in $5 \mathrm{~mm}$ tubes at room temperature. UV spectrum was obtained in a Perkin Elmer apparatus, Lambda 6 model, using DMSO as solvent. IR analysis carried out in a spectrometer with a Bruker Fourier transformer model IF566 using $\mathrm{KBr}$ disks. 


\section{Antimicrobial activity Biochromatography}

The organic extracts and purified BAR were submitted to modified method of biochromatography (Homans and Fuchs, 1970). The samples were applied to silica gel $F_{2554+366}$ Merck plates $(05 \times 10 \mathrm{~cm})$, developed in onedimensional "A" solvent system (toluene/dioxan/acetic acid, 180:45:5, v/v) (Culberson, 1972). The plates, after solvent evaporation, were placed in Petri dishes $(18 \mathrm{~cm})$ and over them, was placed a layer $(54 \mathrm{~mL})$ of solid medium Mueller-Hinton, previously inoculated with a $S$. aureus suspension $(500 \mu \mathrm{L})$ at $10^{7}$ $\mathrm{CFU} / \mathrm{mL}^{-1}$ (strains IC 155 or IC 27), from culture collection of Antibiotic Department of Universidade Federal de Pernambuco, Brazil. The results were evaluated by halo formation around the active substance of the extract, separated by TLC.

\section{Determination of minimal inhibitory concentration (MIC)}

The MIC against four resistant $S$. aureus strains was estimated in vitro for barbatic acid. Ciprofloxacine chlorydrate was used as standard. The following strains were used: S. aureus CI 155, CI 27 and 311 (from vaginal secretion, multiresistent); S. aureus CI 404 (from oropharynx). It is worthy to mention that $S$. aureus CI 404, 155, 311 and CI 27, are resistant to several antibiotics, among them: amicacine, cafotaxime, chloramphenicol, erythromycine and tetracycline. S. aureus CI 311 wasthe more resistant, with additional resistance to cephalotine, peniciline and CI 155 to sulfonamides.

The barbatic acid and ciprofloxacine were weighed and solubilized in acetone and water, respectively, to obtain stock solutions of $2000 \mu \mathrm{g} / \mathrm{mL}$ to barbatic acid and $1000 \mu \mathrm{g} / \mathrm{mL}$ to ciprofloxacine chlorydrate (National Committee for Clinical Laboratory Standards, 2001; Cleeland and Gunberg, 1986). The Petri dishes containing acetone were added to experiments to assure a possible intrinsic effect of this solvent.

\section{RESULTS AND DISCUSSION}

Chemical characterization of $C$. aggregata and identification of barbatic acid (BAR)

In the thin layer chromatogram (TLC) of ether, chloroform and acetone extracts, spots with Rf 29 were shown. They were in agreement with the purified and standard barbatic acid (Fig. 1).

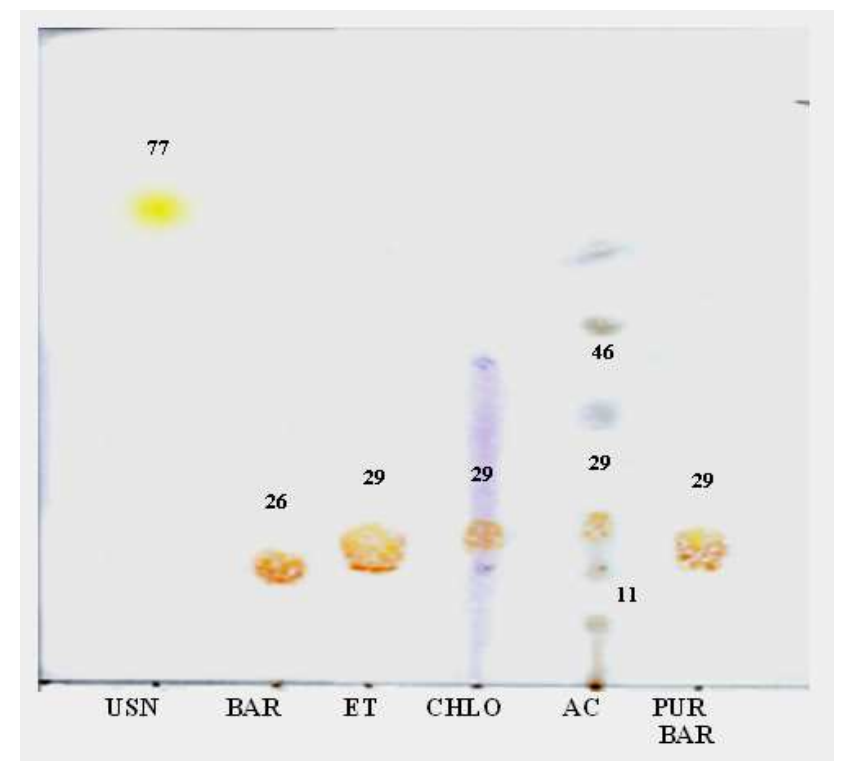

Figure 1 - Thin layer chromatogram of organic extracts of Cladia aggregata (Sw.) Nyl. Captions: UNS - standard usnic acid; BAR - standard barbatic acid; ET - ether extract; CHLO chloroform extract; AC - acetone extract; PUR BAR - purified barbatic acid. Numbers means the spots' Rf values. 
The analysis of organic extracts and purified barbatic acid through liquid chromatography (HPLC) ratified the data obtained by TLC, showing the highest content of barbatic acid in the ether extract (92.9\%), and the lowest in chloroform and acetone extracts $(82.4 \%$ and $66.3 \%$ ), with a retention time (RT) around $19 \mathrm{~min}$, apart from other compounds also detected in lowest content by TLC (Fig. 2). The barbatic acid $\left(\mathrm{C}_{19} \mathrm{H}_{20} \mathrm{O}_{7}\right)$, through elemental analysis, showed $63.33 \% \mathrm{C}$ and $5.55 \% \mathrm{H}$. For experimental calculation of purified barbatic acid, the results were C $62.48 \%$ and $\mathrm{H} 5.44 \%$.

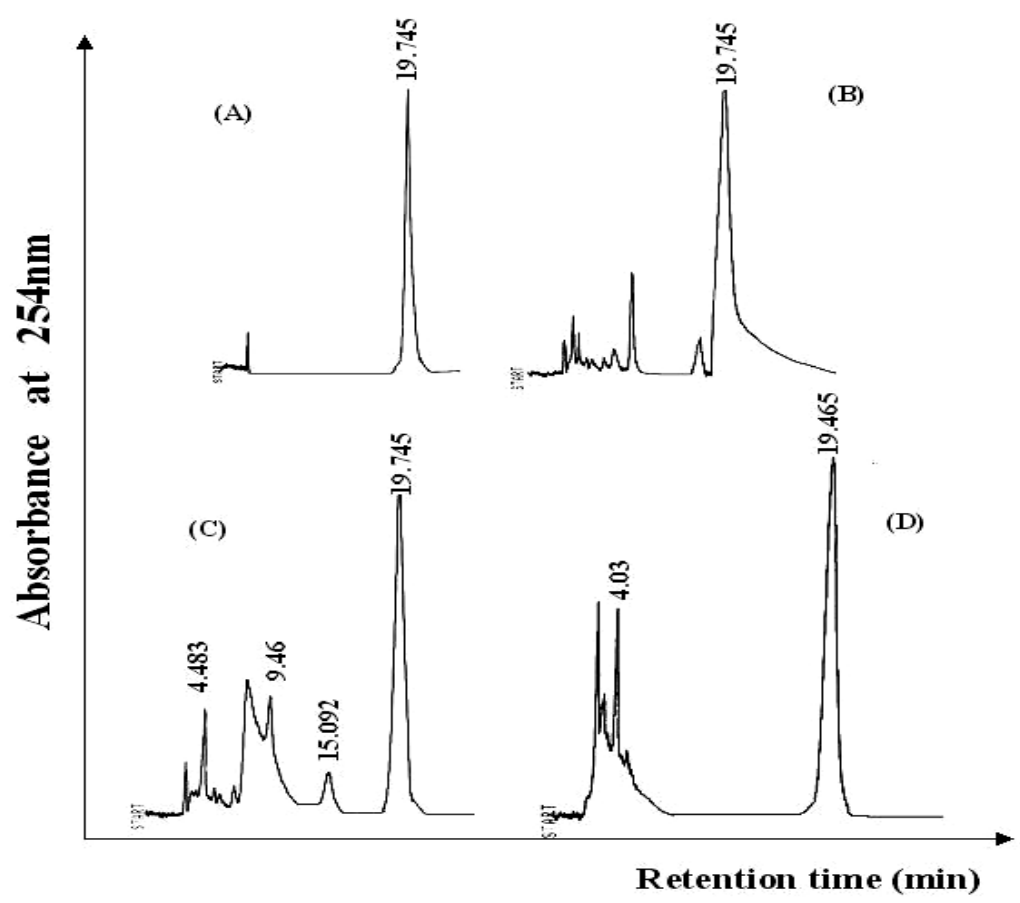

Figure 2 - Liquid chromatogram of purified barbatic acid (A) and organic extracts: ether (B), chloroform (C) and acetone (D) from Cladia aggregata (Sw.) Nyl.

Spectroscopic analysis of purified barbatic acid showed UV $\lambda$ nm (log $\varepsilon)$ : 277 (4.28), 304 (3.82). IR $\lambda^{\max } \mathrm{cm}^{-1}$ whose spectrum demonstrated an aromatic $v \mathrm{C}-\mathrm{H}$ (3100), $\mathrm{CH}_{3}$ vas and vs (2990 and 2940), $v \mathrm{C}=\mathrm{O}$ ester (1720), $v \mathrm{C}=\mathrm{O}$ from conjugated ester (1670), aromatic $\vee \mathrm{C}=\mathrm{C}(1570$ and 1500), $\delta$ as and $\delta$ s of $\mathrm{CH}_{3}$ (1450 and 1380), $v \mathrm{C}$ - O of ester (1230 and 1130). ${ }^{1} \mathrm{H}$ NMR $(300 \mathrm{MHz}$, DMSO-d $\left.\mathrm{d}_{6}\right): \delta 1.99\left(3 \mathrm{H}, s, \mathrm{Me}-8^{\prime}\right), 2.00(3 \mathrm{H}, s$, Me-8), 2.47 (3H, s, Me-9'), 2.56 (3H, $s, \mathrm{Me}-9$ ), $3.86(3 \mathrm{H}, s, \mathrm{MeO}-4), 6.60(1 \mathrm{H}, s, \mathrm{H}-5), 6.69(1 \mathrm{H}$, $s, \mathrm{H}-5), 10.73(1 \mathrm{H}, s, \mathrm{HO}-2)$. In this protonic analysis, the peaks registered at $1.99 ; 2.00 ; 2.47$ and $2.56 \mathrm{ppm}$ corresponding to singlets of methyl groups, in 8', 8, 9' and 9. In $3.86 \mathrm{ppm}$, a singlet was detected due to the presence of a methoxy group in 4. In relation to protons, the singlets were detected at 6.60 and $6.69 \mathrm{ppm}$, corresponding to 5 and 5', and hydroxyls of aromatic rings, also in a singlet form, were detected at $10.73 \mathrm{ppm} .{ }^{13} \mathrm{C}$ NMR (75 MHz, DMSOd 6 ): $\delta 8.1(\mathrm{Me}-8), 22.8$ (Me-9), 9.1 (Me-8'), 23.8 (Me-9'), 55.7 (MeO-4), 110.0 (C-1), 151.8 (C-2), 106.3 (C-4), 161.3 (C-4), 107.1 (C-5), 138.9 (C-6), 168.6 (C-7), 159.4 (C1'), 111.4 (C-2'), 161.1 (C-3'), 116.1 (C-4'), 139.0 (C-5'), 116.1 (C-6')173.2 (C-7'). In this analysis, the signals $\delta 8.1 ; 22.8 ; 9.1$ and $23.8 \mathrm{ppm}$ corresponded to methyl of carbon atoms in $8,9,8^{\prime}$ and 9'. In $55.7 \mathrm{ppm}$, the methoxy group of carbon 4 was registered. Every spectroscopic data, as well as the elemental analysis confirmed the barbatic acid chemical structure (Fig. 3). 


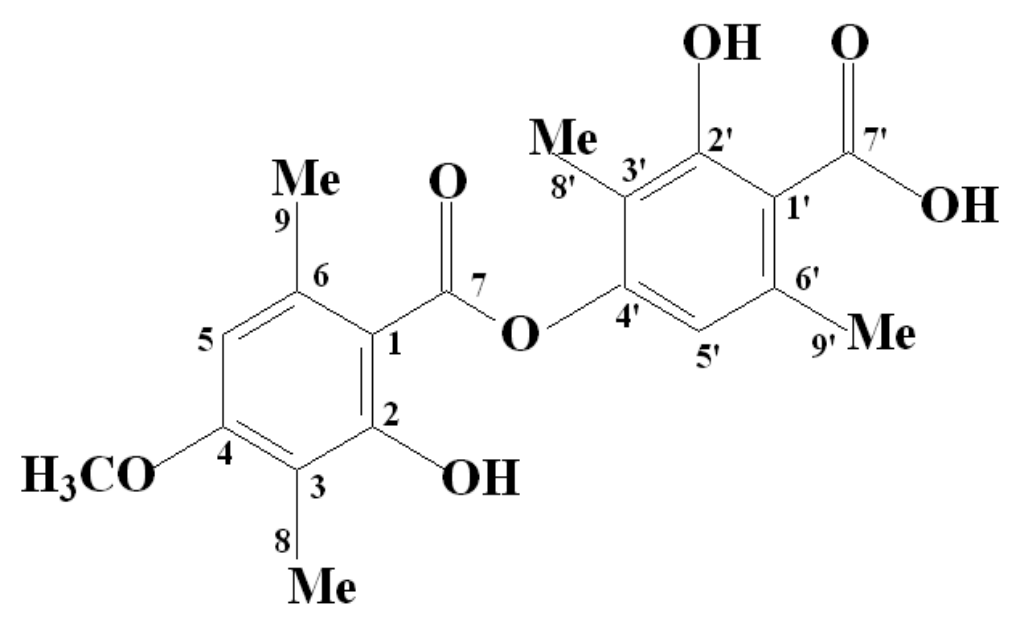

Figure 3 - Structure of barbatic acid $\left(\mathrm{C}_{19} \mathrm{H}_{20} \mathrm{O}_{7}\right)$, according to spectroscopic analysis. Molecular weight 360.36 ; melting point $185-186^{\circ} \mathrm{C}$. Numbers 1 to 9 and 1' to 9' refer to carbon of the molecule.

C. aggregata produces stictic, constictic, norstictic and cryptostictic acids, but samples from Brazil have a barbatic acid chemotipe as dominant (Ahti et al., 1993). Filson (1981) reported ursolic, barbatic, 4-O-demethyl-barbatic, fumarprotocetraric, protocetraric, homosekikaic and norstictic acids, besides some unknown substances and triterpenes. The stictic acid was reported by Galloway (1985) and diffractaic acid by Kantvillas and Elix (1987). Ahti and Kashiwadani (1984) recognized these substance complex described by Filson (1981) in nine Chilean specimens. They concluded that the chemical strain containing the fumarprotocetraric acid complex (fumarprotocetraric and protocetraric acids, besides $\mathrm{Cph}_{1}$ and/or $\mathrm{Cph}_{2}$ substances) were restricted to one specific area, while those that belonged to barbatic acid chemical strain were distributed in other areas. On the other hand, Ahti and Lai (1979) described $C$. aggregata from Taiwan, and found only barbatic acid in the examined samples. This species is considered highly variable in its chemistry (Stenroos, 1988). Pereira et al. (2002) detected usnic and stictic acids in samples from Minas Gerais State.

Ahti et al. (1993) found the barbatic acid as major compound of C. aggregata from Coastal Brazilian Northeast. Its chemical composition can vary according to the geographic area of occurrence and season (Huovinen and Ahti, 1986). The studied material from Brazilian Northeast, in Bonito County, showed a high content of barbatic acid, whose purified form was in agreement to literature data (Huneck and Yoshimura, 1996).

\section{Antimicrobial assays}

The purified barbatic acid and organic extracts of C. aggregata were evaluated as microbial agents. The material, when evaluated through biochromatographic assays, showed inhibition (halo around purified barbatic acid), and this compound in the extract was one of the active principles of $C$. aggregata. The interception between the inhibition halos of extracts and purified BAR against $S$. aureus, strains 155 and IC 27 , suggested an interaction of this acid and other substances in the extract.

After observation of antimicrobial activity exerted by lichen products, the minimum inhibitory concentration (MIC) of purified barbatic acid for IC 27, IC 155 and IC 311 strains, was determined. The MIC varied among the strains of $S$. aureus. It was $50 \mu \mathrm{g} / \mathrm{mL}$ for all the strains, except for highly resistant IC 404, whose MIC was $100 \mu \mathrm{g} / \mathrm{mL}$.

Several studies were conducted with lichen compounds (Ingólfssdóttir et al.., 1985; Perry et al.., 1999; Ribeiro et al.., 2002). In addition, similar results of synergism between lichen substances were observed, after submission of $B$. subtilis to ether extract of Heterodermia leucomela that contained high content of atranorin, and zeorin as accessory substance. Thus, the biochromatography assays showed the action of substances contained in the extracts from $C$. aggregata, besides the barbatic acid. It was also 
possible due to the action of usnic acid present in the extract, and / or its interaction with BAR (Falcão et al., 2002).

When compared to other lichen acids, the MIC was around $50 \mu \mathrm{g} / \mathrm{mL}$. For example, usnic acid showed MIC of $32 \mu \mathrm{g} / \mathrm{mL}$ against Mycobacterium aurum and between $30-40 \mu \mathrm{g} / \mathrm{mL}$ for Methyl- $\beta$ orcinolcarboxylate against Pseudomonas aeruginosa. This compound, when evaluated against $S$. aureus showed high MIC, between 80$160 \mu \mathrm{g} / \mathrm{mL}$. In contrast to these results, Piovano et al. (2002) found low MIC $(15-17 \mu \mathrm{g} / \mathrm{mL})$ of divaricatic and difractaic acids against $S$. aureus. It is known that phenolic compounds, in general, are capable of ionic dissociation (Mueller, 2001; Randhir et al., 2004), which makes possible to justify the antimicrobial activity of purified barbatic acid.

The process of $\mathrm{H}^{+}$dissociation can lead to an acidification of plasmatic membrane surface of microorganism, resulting in $\mathrm{H}^{+}$-ATPase rupture that is required for ATP synthesis (Vattem et al., 2004; Maeda et al., 1999). Besides, it causes intracellular coagulation of cytoplasm constituents, leading the cell to death, or inhibiting its growth (Adham et al., 1998). The Gram positive bacteria are more sensible to these compounds by presenting a simple membrane (Vattem et al., 2004).

Despite the necessity for more detailed studies about the action mechanism of lichen substance against microorganisms, the in vitro effect of barbatic acid against $S$. aureus strains was evident. Apparently, microclimate conditions found in Bonito County induced $C$. agregata to produce high content of barbatic acid, and usnic acid in less amount, leading to antimicrobial action.

\section{ACKNOWLEDGEMENTS}

One of the authors (E. C. Pereira) thanks the Brazilian Council for Scientific and Technological Development (CNPq) for individual grant.

\section{RESUMO}

A composição química e a atividade antimicrobiana da Cladia aggregata (Sw.) Nyl. foram avaliadas. O ácido barbático, um depsideo obtido da $C$. aggregata, foi espectroscopicamente analisado e testado, bem como o extrato orgânico. $\mathrm{O}$ extrato e a substância purificada foram testadas contra 4 linhagens de Staphylococcus aureus multi resistentes. A estrutura do ácido barbático foi confirmada através de ensaios de CCD, CLAE, IV, RMN $\left({ }^{1} \mathrm{H} ;{ }^{13} \mathrm{C}\right)$, UV e analise elementar (r). O biocromatograma mostrou a ação deste composto junto com outras substâncias contidas no extrato orgânico, sugerindo a ação sinérgica, a CMI do ácido barbático mostrou o mesmo nível de inibição de outras substâncias liquênicas.

\section{REFERENCES}

Honda, N. K. and Vilegas. W. (1999), A Química de Liquens. Química Nova. 22, 25-55.

Piovano, M., J. A. Garbarino, F. A. Giannini, E. R. Correche, G. Feresin, A. Tapia, S. Zacchino and R. Enriz. (2002), Evaluation of antifungal and antibacterial activities of aromatic metabolites from lichens. Boletin de la Sociedad Chilena de Química. 47, 235-240.

Llano, G. A. (1951), Economic uses lichens. Smithsonian Institution Publication. 4040, 385-422.

Santos, N. P., S. C. Nascimento, M. S. O. Wanderley, N. T. Pontes-Filho, J. F. Silva, C. M. M. B. de Castro, E. C. Pereira, N. H. Silva, N. K. Honda and N. S. Santos-Magalhães, N. S. (2006), Nanoencapsulation of usnic acid: an attempt to improve antitumor activity and reduce hepatotoxicity. European Journal of Pharmaceutics and Biopharmaceutics. 64, 154160.

Vijayakumar, C. S., S. Viswanathan, M. K. Reddy, S. Parvathavarthim and E. Sukumar. (2000), Antiinflamatory of $(+)-$ usnic acid. Fitoterapia. 71, 564-566.

Maia, M.B.S., N. H. Silva, E. F. Silva, M. T. J. Catanho, A. R. P. Schuler and E. C. Pereira, E. C. (2002), Antinoconceptive activity of crude extracts and atranorin obtained from lichen Cladina dendroides (dês. Abb) Ahti. Acta Farmaceutica Bonaerense. 21, 259-264.

Falcão, E. P., N. H. Silva, N. B. Gusmão, S. M. Ribeiro, N. K. Honda, N. K. and E. C. Pereira. (2002), Atividade Antimicrobiana de compostos fenólicos do líquen Heterodermia leucomela (L.) Poelt. Acta Farmaceutica Bonaerense. 21, 43-49.

Ingólfsdóttir, K. (2002), Molecules of interest usnic acid. Phytochemistry. 61, 729-736.

Carvalho, E. A. B., P. P. Andrade, N. H. Silva, E. C. Pereira and R. C. B. Q. Figueiredo. (2003), Effect of usnic acid from Cladonia substellata on Trypanosoma cruzi in vitro: na ultrastrutural study. Mícron. 36, 155-161. 
Rancan, F., S. Rosan, K. Boehm, E. Fernández, M. E. Hidalgo, W. Quihot, C. Rubio, F. Boehm, H. Piazena and U. Oltmanns. (2002), Protection against UVB irradiation by natural filters extracted from lichens. Journal of Photochemistry and Photobiology B. 68, 133-139.

Krishna, M. V. B., D. Karunasagar and J. Arunachalam. (2002), Study of mercury pollution near a thermometer factory using lichens and mosses. Environmental Pollution. 124, 357-360.

Monnet, F., F. Bordas, V. Deluchat, P. Chatenet, M. Botineau and M. Baudu. (2005), Use of the aquatic lichens Dermatocarpon luridum as bioindicador of copper pollution: accumulation and cellular distribution tests. Environmental Pollution. 138, 455461.

Mueller, K. (2001), Pharmaceutically relevant metabolites from lichens. Applied Microbiology and Biotechnology. 56, 9-16.

Randhir, R., Y-T. Lin and K. Shetty. (2004), Stimulation of phenolic, antioxidant and antimicrobial activities in dark germinated mung bean sprouts in response to peptide and phytochemical elicitors. Process Biochemistry. 39, 637-646.

Vattem, D. A., Y-T. Lin, R. G. Lable and K. Shetty. (2004), Phenolic antioxidant mobilization in cranberry pomace by solid-state bioprocessing using food fungus Lentinus edodes and effect on antimicrobial activity select food borne pathogens. Innovative Food Science Emerging Technology. 5, 81-91.

Legaz, M. E., C. Vicente, C. Ascaso, E. C. Pereira and L. Xavier-Filho. (1986), Pigment analysis of sun and shade populations of Cladonia verticillaris. Biochemistry Systematic and Ecology. 14, 575-58.

Filson, R. B. (1981), A revision of the lichens genus Cladia Nyl. Journal Hattori Botany Laboratory. 49, $1-75$.

Ahti, T. Lichenologist. (1980), 12, 25-133

Ahti, T., S. Stenroos and L. Xavier-Filho. (1993), The lichen family Cladoniaceae in Paraiba, Pernambuco and Sergipe, Northeast Brazil. Tropical Biology. 7, 55-70.

Pereira. E. C., S. C. Nascimento, R. M. C. Lima, N. H. Silva, A. F. M. Oliveira, E. Bandeira, M. Boitard, H. Beriel, C. Vicente and M. E. Legaz. (1994), Analysis of Usnea fasciata crude extracts with antineoplasic activity. Tokai Journal of Experimental and Clinical Medicine. 19, 47-52.

Pereira, E. C., N. H. Silva, G. M Campos-Takaki, L. Xavier-Filho, M. E Legaz and C. Vicente. (1997), Antimicrobial activity of biologically-active compounds from lichen Cladonia crispatula. Boletin. Ecotrópica-Ecosistemas Tropicales. 31, 09-19.
Pereira, E. C., N. H. Silva, E. S. Brito, J. Cruz and M. I. Silva, M. I. (1996),. Atividade antimicrobiana de liquens Amazônicos I: Cladonia corallifera e Cladonia substellata. Revista Universidade do Amazonas. Série: Ciências Biológicas.1, 65-77.

Asahina, Y. and S. Shibata. (1954), Chemistry of lichen substances. Japan Society for the Promotion of Science. 239 p.

Culberson, C. F. J. (1972), Improved conditions and new data the identification of lichen products by a standardized thin-layer chromatographic method. Journal of Chromatography. 72, 133-25.

Legaz, M. E. and C. Vicente. (1983), Endogenous inactivators of arginine decarboxylase and agmatine amidinohydrolase en Evernia prusnastri thallus. Journal of Plant Physiology. 71, 300-302.

Homans, A. L. and A. Fuchs. (1970), Direct bioautography on thin layer, cromatograms as method for detecting fungitoxic substances. Journal of Chromatography. 51, 327-329.

National Committee for Clinical Laboratory Standards. (2001)

Cleeland, R. and E. Grunberg. (1986), Laboratory evaluation of new antibiotics in vitro and experimental animal. Pp. 825-876. In: Wiliams Watkins (Ed.), Antibiotics in Laboratory Medicine, Baltimore.

Galloway, D. J. (1985), Flora of New Zealand lichen. Hasselberg, Wellington. 622p.

Kantvilas, G. and J. A. Elix. (1987), New species of Cladia (lichenized Ascomycotina) from Tasmania. Mycotaxon. 29, 99-205.

Ahti, T. and Kashiwadani. (1984), The Lichen genera Cladia, Cladina and Cladonia in Southern Chile. pp. 125-151. In: Studies on Cryptogams in Southern Chile. $1^{\text {a }}$ ed. Inoue.

Ahti, T. and M. J. Lai. (1979), The genera Cladonia, Cladia in Taiwan. Annales Botanici Fennici.16, 228236.

Stenroos, S. (1988), The family Cladoniaceae in Melanesia. Annales Botanici Fennici.. 25, 207-217.

Pereira, E. C., L. H. C. Andrade, N. H. Silva and C. Vicente. (2002), Anticonceptive activity of crude extracts and atranorin obtained from lichen Cladina dendroides (des. Abb). Acta Farmaceutica Bonaerense. 21, 259-264

Huovinen, K. and T. Ahti. (1986), The composition and contents of aromatic lichen substances in Cladonia, section Unciales. Annales Botanici Fennici. 23, 173188.

Huneck, S. and I. Yoshimura. (1996), Identification of lichen substances. Springer, Verlag, Berlin. 492 p. 
Ingólfsdóttir, K., Bloomfield, S., Hylands, P. J. (1985), In vitro evaluation of the antimicrobial activity of lichen metabolites as potential preservatives. Antimicrobial Agents Chemotherapy. 28, 289-292.

Perry, N. B., M. H. Benn, N. J .Brennan, E. J. Burgess, G. Elliss, D. J. Galloway, S. D. Lorimer and R. S. Tangney. (1999), Antimicrobial, antiviral and citotoxic activity of New Zeland lichens. Lichenologist. 31, 627-636.

Ribeiro, S. M., E. C. Pereira, N. H. Silva, E. P. Falcão, N. B. Gusmão, N. K. Honda, and W. Quilhot. (2002), Detection of antibacterial activity of lichen substances through microdiluition tests. In: S. Calvelo, T. Feuerer (Eds.) Lichenology in Latin America.187-194.
Maeda, T., Y. Manabe, M. Yamamoto, M. Yoshida, K. Ojazaki, H. Nagamune and H. Kourai. (1999), Synthesis and antimicrobial characteristics of novel biocides, 4,4- (1,6- hexamethylene dioxydicarbonyl) bis (1- alkylpiridinium iodines). Chemical and Pharmaceutical Bulletin. 47, 1020.

Adham, I., A. J. Dinning, I. Eastwood, P. Austin, and P. J. Collie. (1998), Cell membrane effects of some common biocides. Journal of Industrial Microbiology and Biotechnology. 21, 6.
Received: April 30, 2007 ; Revised: September 04, 2007; Accepted: April 27, 2009. 